\section{Types of Predicate-Subject Constructions in Indonesian}

\author{
Wagiati (Corresponding author) \\ Indonesian Departement, Faculty of Humanities, Padjadjaran University, Indonesia \\ Jalan Raya Bandung - Sumedang Km. 21 Jatinangor, Bandung, Indonesia \\ E-mail: wagia03ti@yahoo.com
}

\begin{abstract}
Dadang Suganda
Indonesian Departement, Faculty of Humanities, Padjadjaran University, Indonesia

E-mail: dadang_sumri@yahoo.com
\end{abstract}

Bambang Kaswanti Purwo

English Departement, Atmadjaya University, Jakarta, Indonesia.

E-mail: bkaswanti@gmail.com

Wahya

Indonesian Departement, Faculty of Humanities, Padjadjaran University, Indonesia

E-mail: rizka_cikal@yahoo.com

Received: August 14, 2013 Accepted: September 6, 2013 Published: October 25, 2013

doi:10.5296/ijl.v5i5.4453 URL: http://dx.doi.org/10.5296/ijl.v5i5.4453

\begin{abstract}
In Indonesian sentences, the subject typically precedes the predicate. However, there are certain structures where the subject occurs after the predicate. Thus, Indonesian sentences can follow subject-predicate and predicate-subject constructions. Based on the data analyzed, there are several types of predicate-subject constructions in Indonesia. They are: (1) interrogative construction, (2) imperative construction, (3) exclamatory construction, and (4) declarative construction. Based on the types of words occurring as predicate, the declarative
\end{abstract}




\section{Macrothink}

International Journal of Linguistics ISSN 1948-5425 2013, Vol. 5, No. 5

construction is categorized again into (1) declarative construction with a noun phrase predicate, (2) declarative construction with a numeral-phrase predicate, (3) declarative construction with an adjective-phrase predicate, and (4) declarative construction with a verb phrase predicate.

Keywords: Subject, Predicate, Construction, Structure 


\section{Introduction}

Simple Indonesia sentences have the following characteristics: (1) they consist of one clause, (2) they have complete components, (3) the components occur in the most general order, and (4) they do not contain interrogation or negation. In relation to characteristic (3) above, that the components occur in the most general order, the predicate is always placed after the subject in Indonesian. The most general order of occurrence is, therefore, subject-predicate. However, based on the data analyzed, predicates can also occur before subjects. Thus, in Indonesian, a predicate can be placed on either the left or right of the subject. In other words, both the subject-predicate and predicate-subject structures are acceptable in Indonesian.

Consistent with the above, Kaswanti Purwo (1989:2) asserts that Indonesian is a language that allows SV and VS (that is S-P and P-S) occurrences. With regard to the position of the subject in a sentence, Sugono (1985: 34-35) explains that a subject can occupy two positions, on the left or right of the predicate.

Synchronic in nature, the research uses the descriptive method, which aims to provide a description, to draw a systematic, factual, and accurate picture of the data, characteristics, and phenomena studied. The method also suggests that research be conducted based merely on the facts available or phenomena occurring among the speakers of a language in order to result in a description that is faithful to the facts (Sudaryanto, 1992: 62). The method and technique used in the research is the distributional method, under which the determining factors are taken from the language studied itself (Sudaryanto, 1993: 15). The data are taken from different varieties of texts, including fictions, journalistic articles, and scientific writings.

\section{Subject-Predicate and Predicate-Subject Structures in Indonesian}

Discussions about the predicate-subject structure depart from the concepts of subject, predicate, subject-predicate structure and predicate-subject structure. In Indonesian, sentence subjects and predicates can be identified from their (1) formal characteristics and (2) intonation. Sugono(1995:43-48) asserts that based on the fillers' categories, subjects in Indonesian can be (i) a noun phrase, (ii) a verb (+ 'itu'), (iii) an adjective (+ 'itu'), (iv) a prepositional phrase, and (v) a noun clause. Meanwhile, predicates have, among others, the following characteristics: (i) they answer the questions 'why' or 'how', (ii) they are words, namely 'adalah' or 'ialah', (iii) they can be put into negative, and (iv) they can be added with aspect and modality words (Sugono, 1997: 48-54).

The concepts of subject-predicate and predicate-subject structures are based on Kaswanti Purwo (1987). Kaswanti Purwo (1987:13) distinguishes the structure-predicate structure from the predicate-subject structure based on their intonation. He provides the following examples.

(1) a. Mereka tersentak. (subject-predicate)

They are startled.

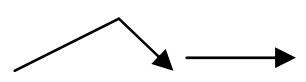


b. Tersentak mereka. (predicate-subject)

Startled are they.

(2) a. Yang menangis adik. (subject-predicate)

The one who cried was (my) brother.
b. Adik
$\longrightarrow$
b. Adik yang menangis. (predicate-subject)
It was (my) brotherwho cried.

By observing the above intonation pattern, it can be concluded that in the subject-predicate construction (b), there is only one rising intonation. The intonation of the predicate constituent remains the same in the subject-predicate construction (a) and the predicate-subject construction (b). However the subject constituent undergoes an intonation change; in the predicate-subject structure, the intonation is flat (Kaswanti Purwo, 1987: 13-14).

\section{Types of Predicate-Subject Structures in Indonesian}

In terms of communicative functions, predicate-subject structures are categorized into: (1) negative construction, (2) imperative construction, and (3) exclamatory construction, and (4) declarative construction. The declarative construction has the most variations among the four types of construction. Predicates in the declarative construction are formed by (1) noun phrases, (2) numeral phrases, (3) adjective phrases, and (4) verb phrases.

\subsection{Interrogative Construction}

The interrogative construction referred to in this research refers to constructions using interrogative pronouns functioning as the predicate $(\mathrm{P})$. Based on the data analyzed, the interrogative pronouns that can function as $\mathrm{P}$ are (1) 'apa', (2) 'siapa', (3) 'berapa', (4) 'yang mana', (5) 'bagaimana', (6) 'ke mana' and (7) 'di mana'. The following are examples of P-S structures with negative construction.

(1) a. “Apa / jawaban Pater waktu itu?” (S: 115)

"What was Pater's answer then?"

b. Siapa / namamu? (LB: 30)

What / is your name?

c. Berapa/ nilai pinjamannya? (T, 3-9/10/11: 102)

How much/ was the amount of the loan?

d. Yang Mana /Rumah kita ? (KO, 15/10/10)

Which (one) / is our house?

e. Bagaimana / udara di sana? (LB: 2)

How / is the weather there?

f. Ke mana / pasanganmu? (S: 38)

Where / is your partner? 
g. Di mana / habitatnya? (LP: 183)

Where / is its habitat?

(2) a. “Apa /yang kalian bicarakan tadi?" (LB: 97)

"What / were you talking about just now?"

b. Siapa / yang jatuh? (S: 68)

Who / fell?

c. ...berapalyang mereka butuhkan untuk melanjutkan hidup, .... $(\mathrm{KO}, 18 / 4 / 11)$

...how much / do they need to continue (their) life, ...

d. Tapi, yang mana / yang benar-benar bisa membantu menurunkan berat badan? But, which (one) / can really help reduce weight?

e. Bagaimana / yang tidak tampak? (KO, 23/3/13)

What / about the invisible?

f. ... ke mana/yang mereka tuju,...? (KO, 29/5/09)

... where / are they heading, ...?

All the above constructions consist of two consist of two constituents: first, an interrogative pronoun and second, a noun phrase (NP). All the interrogative pronouns in the examples above function as predicates $(\mathrm{P})$ and the subsequent FNs function as subjects $(\mathrm{S})$. Thus, the structure of the constructions is P-S. As can be seen, the S in example (2) is preceded by the word 'yang', while in example (1), it is not. The word 'yang' in (2) occurs because the P is followed by a verb phrase (VF). Therefore, it can be concluded that the word 'yang' functions to nominalize the verb phrase (VF).

\subsection{Imperative Construction}

An imperative construction is marked with the use of an imperative verb. Indonesian imperative verbs can be (1) intransitive verbs and (2) transitive verbs. Based on the data analyzed, imperative verbs can be (1) stem verb, (2) verb with prefix 'ber-", and (3) $m e N$-verb. As for imperative verbs, they are all not preceded with a prefix, though some have $-i$ or $-k a n$ suffixes. These imperative verbs can optionally be followed with the particle -lah. The presence or absence of the particle -lah after these verbs does not affect their imperative nature. Notice the following examples.

a. "Pergilah / Kau!" (KO, 10/1/12)

b. Berenanglah / engkau / di permukaan, .... (KO,3/9/13)

Swim / you / on the surface, ...

c. Menyeberanglah / kamu....(www.godrules.net, 2013)

Cross / you ...

(4) a. Ambil/ semua yang kau inginkan. (cerpenkompas.wordpress.com, 13/3/11)

Take / everything you want.

b. ... bersihkan/ komputer masing-masing, ....(KO, 8/7/12)

... clean / your own computer ...

c. ... kunjungilah / pantai-pantai yang ada di dekatnya. (KO, 17/11/12)

... visit / the beaches nearby. 
All the examples above begin with an imperative verb that functions as $\mathrm{P}$. The constituent that comes immediately afterwards is an NP that functions as S. Therefore, the above constructions has a P-S structure.

\subsection{Exclamatory Construction}

Exclamatory construction, also called interjectional construction, is marked with the use of the words, such as 'alangkah', 'betapa', and 'bukan main'. These words precede the P. In this construction, the $\mathrm{P}$ is an adjective tailed with the particle -nya. The $\mathrm{S}$ in this kind of construction can be (1) a noun phrase, (2) a verb phrase, or (3) a clause. Observe the following examples.
a. Alangkah malangnya / Riki. (KO, 18/10/10)
How unfortunate / Riki is.
b. Betapa Sengsaranya / Tidak Punya KTP (KO, 9/1/12)
How difficult / it is to not have an ID card.
c. Bukan main rajinnya / kita beribadah,.... (ahlisyukur.com)
How diligently / we worship (God), ...

Based on the above formal features, the italicized constituents in example (5) are P's and the subsequent constituents are S's. Thus, the above construction has a P-S structure. The S in $(5 b)$ is an $\mathrm{FV}$, and in $(5 \mathrm{c})$, it is a clause.

\subsection{Declarative Construction}

Compared to the previous three constructions, the declarative construction is the most complex because it consists of many sub-types. Based on the categories of the words that function as predicates, this construction is divided into (1) declarative construction with a noun phrase as $\mathrm{P}$, (2) declarative construction with a numeral-phrase $\mathrm{P}$, (3) declarative construction with an adjective phrase as $\mathrm{P}$, and (4) declarative construction with a verb phrase as $\mathrm{P}$.

\subsubsection{Noun-Phrase Predicate}

Noun-phrase predicates are divided further into (a) noun phrase + particle $-l a h$; (b) noun phrase - the S is preceded with the word 'yang'; (c) noun phrase preceded or followed by an adverbial; and (d) the noun phrase 'tak seorang pun'.

\subsubsection{Noun Phrase + Particle '-lah'}

In Indonesian, when the particle -lah is affixed to an NP that originally functions as $\mathrm{S}$, the NP changes into a P. Thus, in a construction where two NPs occur subsequently, the NP to which the particle '-lah' is attached becomes P and the other NP becomes S. From the data studied, it can be concluded that the NPs to which the particle '-lah' is attached can be (1) a proper noun, (2) a noun phrase, (3) a pronoun, and (4) a demonstrative pronoun. The S's are all noun phrases. Look at the following examples.

(6) a. David-lah / yang memperkenalkan Sophie. (LB: 82)

It was David / who introduced Sophie. 
b. Cara-cara analisis yang digunakan itulah / yang disebut metode. (SKF: viii) It is the procedure of analysis used / that is called a method.

c. Akulah / yang mendesaknya. (LB: 220)

It was I / who forced him.

d. Itulah / yang terjadi pada Billy Ray Harris, seorang tuna wisma di Kansas.... It was this / that happened to Billy Ray Harries, a homeless in Kansas ...

The examples above consist of two constituents. Based on the formal features, the italicized constituents are all P's and the subsequent constituents are S's. The four examples above therefore follow a P-S structure.

\subsubsection{Noun Phrase; S preceded by 'yang'}

The construction is formed by two constituents, both of which are NPs. The lingual unit that causes this construction to be regarded as consisting of two constituents is the occurrence of the word 'yang' after the italicized constituent. It is the word 'yang' that marks the boundary between the first and second constituents.

Based on the data analyzed, NP's that come first in the construction can be (1) proper nouns, (2) pronouns, and (3) demonstrative pronouns. As can be seen in the following examples, the second NP's are all preceded with the word 'yang'.

(7) a. "Francine / yang berangkat ke Nice." (LB: 58)

It was Francine / who went to Nice.

b. Akhirnya / saya / yang harus menanggungnya. (S: 6)

Finally / it was I / who had to bear it.

c. "Itu/ yang seharusnya dilakukan. (KO, 22/3/13)

That / was what should have been done.

With the presence of the word ' $y$ ang' after NP, the P-S intonation pattern applies, that is, the italicized constituent must be uttered in a rising intonation, while the subsequent constituent in a flat intonation. With this intonation pattern, the italicized constituent thus functions as $\mathrm{P}$, and the subsequent constituent functions as S. In short, the construction above belongs to the P-S structure.

\subsubsection{Noun Phrase Preceded/Followed by an Adverbial}

This construction is made up of two constituents, both of which are NP's. The first NP is preceded/followed by an adverbial, while the second by 'yang'. Not all adverbials, however, can occur together with NP in this construction. According to the data, the adverbials are: (1) 'hanya/cuma', (2) 'pasti/tentu', (3) 'baru', (4) 'pula', (5) 'bukan', and (6) 'justru'. Semantically, 'hanya/cuma' are both adverbs of certainty; 'baru' is an adverb of time, 'pula' an adverb of addition, 'bukan' an adverb of negation, and 'justru' an adverb of contrast. See the examples below.

(8) a. Hanya kami / yang bersikap tegas soal ini pada pemerintah. (KO, 26/6/08)

Only we / show a firm attitude towards this matter to the government.

b. Cuma camar / yang sesekali berseru dari langit. (S: 13) 
Only seagulls / occasionally squawked from the sky.

c. Pasti dia / yang turun tangan. (KO, 5/9/12)

It had to be he / who intervened.

d. Tentu kami / yang pertama tama diberangus. (sabdo-palon.blogspot.com, 30/9/12)

It was certainly us / who were muzzled in the first place.

e. ... sampai detik ini / baru dia / yang menawarkan bantuan.... (KO, 20/5/11)

... until this moment / only he / has offered help ...

f. Dia pula / yang menghendaki Mantri untuk bermain di San Siro. (KO, 11/4/11) It was also he / who wanted Mantri to play in San Siro.

g. Saya yakin / bukan mahasiswa kami / yang memukul polisi itu. (KO, 2/6/08)

I am sure / it was not our student / who beat the police officer.

h. Justru buah-buahan yang masih hijau / yang dia petik. (LB: 54)

In fact, it is only the fruits that are still green / that he picked.

All the sentences in example (8) consist of two constituents. Both are NPs. The first is preceded/followed by an adverbial, and the second is followed by 'yang'. Which constituent functions as $\mathrm{S}$ and $\mathrm{P}$ can be determined from the intonation pattern. The occurrence of an adverbial and 'yang' after NP requires the P-S intonation pattern to be used. The italicized constituents above must be uttered with rising intonation. The intonation then falls and flattens in the subsequent constituent. Examples (8) above then follow the P-S structure.

\subsubsection{The Noun Phrase 'tak seorang pun'}

In Indonesian, there are constructions which begin with the NP 'tak seorang pun'. This constituent is usually followed by an NP preceded by 'yang'. However, it can also be followed by a relative clause constituent. Observe the following examples.

(9) a. ... tak seorang pun / yang menyambangi dan membeli dagangannya. (KO/3/1/12) ... no one / came and bought his merchandise.

b ... tak seorang pun / yang boleh menikahinya." (KO/22/12/10) ... no one / is allowed to marry her.

c. ... tak seorang pun / yang tidak mengetahui Arifin Panigoro (65).... (KO, 19/4/10) ... no one / doesn't know Arifin Panigoro.

(10) a ... tak seorang pun / kiper yang punya jaminan posisi di starting eleven "Der Panzer" ... no (goal) keeper / has a guaranteed starting eleven position in "Der Panzer"

The above sentences have two constituents. The boundary between both constituents is between 'tak seorang pun' and 'yang' in (9) and between the NP 'tak seorang pun' and 'kiper' in (10). The first constituent is the $\mathrm{P}$ and the second the S. Thus the structure of both (9) and (10) is P-S.

In (9), the NP 'tak seorang pun' is immediately followed by 'yang', while in (10), it is not so. This is because the $\mathrm{S}$ in (9) is a VF, while in (10) it is a nominal, namely a relative clause. The word 'yang' here nominalizes a non-nominal constituent. 


\subsubsection{Numeral-Phrase Predicate}

This construction is made up of an indefinite numeral phrase (Num P). The Num P's in this construction are (1) 'banyak' and (2) 'sedikit'. It needs to be noted here that the P and S in the construction is separated by the constituent 'banyak'/'sedikit' and the subsequent nominal. This particular feature must be underlined considering that both 'banyak' and 'sedikit' can also function as adverbs. As adverbs, 'banyak' and 'sedikit' modifies the subsequent constituent. As adverbs, the words 'banyak' and 'sedikit', together with the subsequent constituent forms a unity, for example, 'banyak orang' in 'Saya melihat banyak orang di lapangan'; 'banyak membaca' in 'Kami harus banyak membaca'; or 'sedikit pewangi' in 'Tambahkan sedikit pewangi'.Unlike these examples, 'banyak' and 'sedikit' in Num P construction stand on their own as $\mathrm{P}$, as exemplified in the following.

a. ... jangan khawatir / banyak / orang yang akan mendoakan. (LP: 73) ... don't worry / many / people will pray.

b. Banyak / orang yang percaya bahwa mereka hidup di pulau-pulau kecil .... (LP: 184)

Many / people believe that they live in small islands ...

c. ...tidak banyak / peneliti bahasa yang terlalu peduli dengan teori akbar;.... (SKF: xi)

... not many / language researchers really care about grand theories; ...

(12) a. Hanya sedikit / manusia yang pandai bersyukur(KO, 12/2/2013)

Only very few / people are truly thankful (to God).

b. Tidak sedikit/orang yang malas minum air putih.... (KO, 12/2/2013)

... not a few / people are unwilling to drink water ...

c. Tak sedikit / orang yang mengurungkan niat untuk mendonorkan darahnya karena mitos ... (KO, $7 / 1 / 10)$

Not a few / people were discouraged from donating their blood.

The sequence in (11)-(12) is P-S, as can be proven from the intonation. The intonation is rising for the italicized constituent, then falling and flat for the subsequent constituent.

\subsubsection{Adjective-Phrase Predicate}

$\mathrm{P}-\mathrm{S}$ structure can occur in a construction whose $\mathrm{P}$ is an adjective. In Indonesian, the adverbs 'sungguh' and 'amat' form an adjective phrase (Adj. P). In addition, the negative 'tidak' can also co-occur with an adjective, and together with the adjectiveit modifies, forms an adjective phrase. The $\mathrm{S}$ in this construction can be (1) a noun phrase, (2) a verb phrase, and (3) a clause. Notice the following examples.

a. Sungguh bahagia / artis senior Dewi Irawan.... (KO, 10/12/11)
Very happy / was senior artist Dewi Irawan ...
b. Amat menyenangkan / melihat film yang begitu sederhana, ....

It was very entertaining / to watch so simple a film ...

c. Tidak benar / bahwa dia mencoba masuk ke Niger atau sudah tiba di Niger. $(\mathrm{T}, 18 / 9 / 11)$ 
It was untrue / that he attempted to enter Niger or had arrived in Niger.

The examples in (13) consist of two constituents. The italicized constituents are P's, and the subsequent constituents are S's. The P's in the examples above are all adjective phrases, whereas the S's are a noun phrase (13a), a verb phrase (13b), and a clause (13c).

\subsubsection{Verb-Phrase Predicate}

The verbs of the verb-phrase predicates in constructions with P-S structure can be (1) stem verbs, (2) verbs with prefix 'ber-', intransitive verbs with prefix ' $m e N-$ ', and (4) passive verbs. In this discussion, stem verbs are classified further into (1) the verb 'ada' and (2) other stem verbs.

\subsubsection{Stem Verbs}

\subsubsection{The Verb 'Ada'}

Constructions with P-S structure using the verb ' $a d a$ ' are distinguished from constructions with other stem verbs as $\mathrm{P}$ because they show a different behavior. The difference lies in (1) the position of $\mathrm{P}$ to $\mathrm{S}$ and (2) what functions as $\mathrm{S}$. With regard to the position of $\mathrm{P}$ to $\mathrm{S}$, in constructions with the verb ' $a d a$ ' as $\mathrm{P}$, the $\mathrm{P}$ is usually on the left of the $\mathrm{S}$. Meanwhile, where $\mathrm{P}$ is other stem verbs, it is usually placed to the right of $\mathrm{S}$. With regard to $\mathrm{S}$ constituent, in constructions with the verb ' $a d a$ ' as $\mathrm{P}$, the $\mathrm{S}$ can be (1) a noun phrase, (2) a noun phrase preceded by 'yang', and (3) a relative clause. The $\mathrm{S}$ in constructions with other stem verbs as $\mathrm{P}$ is generally a nominal phrase. Notice the following examples.

a. Ada / pelanggaran hak asasi manusia. (T, 12-18/9/11: 38)

There was / a human rights violation.

b. $\quad \boldsymbol{A d \boldsymbol { a }}$ / perhatian sedikit pada fonologi, pragmatik, dan semantik; .... (SKF:12)

There is a little attention / to phonology, pragmatics, and semantics; ...

a. Ada / beberapa sarjana yang berusaha menerapkannya dalam deskripsi .... (SKF: 25)

There are some / scholars who try to apply it in their descpription ...

b. Ada / hal-hal yang perlu dibicarakan terkait Pak Menteri. (T, 12-18/9/11: 28)

There were / matters to discuss about the Minister ...

a. Ada / yang kurahasiakan dari orang tuaku. (S; 127)

There is something / that I keep secret from my parents.

b. $\quad \boldsymbol{A d a}$ / yang berubah di komplek Akademi Kepolisian. (T, 3-9/10/11: 70)

There is something / that has changed at the Police Academy campus.

The data in examples (14)-(16) consist of two constituents. The first constituent is P, and the second S. The S's are NP's in (14),relative clauses in (15), and 'yang' + NPs in (16).

\subsection{Other Stem Verbs}

According to the data, stem verbs that can have a P-S structure include are 'datang', 'hadir', 'hidup', and 'muncul'.Givon (1976) in (Kaswanti Purwo, 1985: 9) calls such verbs 'verbs of emergence", which are generally found in presentative constructions. Kaswanti Purwo (1985:11) further describes that the presentative construction has several characteristics. For 
example: (1) it is generally used to open a paragraph in the form of a simple clause and is not preceded by a conjunction, and (2) it can be preceded by an adverb of place or time. Kaswanti Purwo adds that clauses preceded by an adverb of place or time are typical in S-P inversion. Notice the examples below.

(17) a. Hari itu juga / datang / dari Marseille / seorang wanita muda. (LB: 71)

On that very day/ came / from Marseille / a young woman.

b. Ketika itu / hadir juga / Sindu Malik Pribadi dan Acos -belakangan diketahui bernama asli Iskandar Pasajo. (T, 12-18/9/11: 27)

In the occasion / came also / Sindu Malik Pribadi and Acos-later known originally as Iskandar Pasajo.

In (17) above, the verbs 'datang', 'hidup', 'muncul', and 'hadir', all functioning as predicates, are placed before the subjects, which verify that the constructions is P-S in structure. The examples in (17) are simple clauses that are preceded by adverbs of time. According to the concept of presentative construction discussed by Kaswanti Purwo (1985), the examples in (17) can be categorized as presentative constructions.

Kaswanti Purwo also adds that P-S structure can also occur in complex subjects. He continues that the fronting of a predicate to give the final focus to its complex subject in English is discussed among others by Quirk, et al. (1972), Fowler (1923), and Green (1980) (Kaswanti Purwo,1985: 11). P-S construction with a complex subject is shown in the (18) below.

(18) a. Kemudian / muncul / para tokoh seperti K.A.Abdul Hamid dan Ibrahim bin

Zaidin yang berkorban habis-habisan melanjutkan sekolah kandang itu menjadi sekolah Muhammadiyah. (LP: 23)

Then / emerged / figures like K. A. Abdul Hamid and Ibrahim bin Zaidin, who made a lot of sacrifice to change the pigsty school into the Muhammadiyah school.

b. Di sana, /di luar lingkar tembok Gedong / hidup / komunitas Melayu Belitong yang jika belum punya enam anak belum berhenti beranak pinak. (LP: 50) There, / outside the walls of the Gedong / lived / the Malay Blitong community who,before they had had six children, they would not stop to multiply.

Both sentences in (18) above have a complex subject. In addition, sentence (18)b begins with an adverbial. As shown in (18) a construction having these two features-having a complex subject and preceded with an adverbial, can have a P-S structure.

\subsubsection{Verbs with Prefix 'ber-'}

Verbs with prefix 'ber-' that can have a P-S structure include 'berdiri', 'berkumpul', 'bergulir', and 'berpadu'. As is the case with stem verbs, P-S structure for verbs with prefix 'ber- occurs because (1) the construction is preceded by an adverb of time or place and (2) the construction has a complex subject. See the following examples.

(19) a. Di mulut pintu / berdiri /dua orang guru seperti para penyambut tamu dalam 
perhelatan.(LP: 1-2)

At the door / stood / two teachers like greeters in receptions.

b. Di sana / berkumpul/ratusan sukarelawan dari semua provinsi Jepang.

(T, 12-18/9/11:64)

There / gathered / hundreds of volunteers from all provinces in Japan.

c. Dalam dua pekan terakhir / bergulir /wacana bahwa Presiden Inter Masimmo Moratti ingin membeli Messi. (KO,1/1/10)

In the last two weeks/ has circulated / an issue that Inter's President Masimmo Moratti would like to purchase Messi.

d. Dalam subsistem-subsistem itu / berpadu / dunia bunyi (fonetik) dan dunia makna (semantik), .... (SKF: 12)

In the subsystem / are blended / the world of sounds (phonetics) and the world of meanings (semantics) ...

\subsubsection{Intransitive Verbs with Prefix ' $m e N-$ '}

Intransitive verbs with prefix 'meN-' that can have a P-S structure is, among others, 'melingkar', as exemplified in (20) below.

a. Di dadaku / melingkar / tanda bulat merah kehitam-hitaman, sebuah jejak kemahatololan. (LP: 82)

Around my chest / encircle / round dark-red marks, traces of (my) idiocy.

As with stem verb and 'ber-verb' constructions, the P-S structure in the intransitive 'meN-' construction is marked by (1) the occurrence of an adverbial at the beginning of the construction and (2) the occurrence of a complex subject in the construction. Example (20) shows that the verb 'melingkar', which functions as the predicate, is preceded by and adverbial and followed by a complex subject.

\subsubsection{Passive Verbs}

The passive verbs in constructions with P-S structure are (i) passive verbs without prefix, (ii) passive verbs with prefix 'di-', (iii) passive verbs with prefix 'ter-', and (iv) passive verbs with 'ke-an'.

\subsection{Passive Verbs without Prefix}

Examples of passive verbs without prefix can be seen in (21) below.

(21) a. Saya coret / nama kamu. (Saman: 15)

I crossed out / your name.

b. Kemudian / kulihat lagi / pria cemara angin itu. (LP: 13)

Then / I saw again / the casuarinas man.

c. Kami gotong / tubuh kecilnya / sambil berlari. (LP: 174)

We carried / his small body / as we ran.

The constituent 'saya coret', 'kulihat lagi', and 'kami gotong' in the above examples are all P's and the subsequent constituents are S's. Thus the sentences in (21) have a P-S structure. 


\subsection{Passive Verbs with Prefix ' $d i-$ '}

As with the previous constructions, P-S structure with ' $d i$-' + passive has the following characteristics: (1) the construction begins with an adverb and (2) the construction has a complex subject. Sentences beginning with an adverb are exemplified in (22), and constructions with a complex subject can be seen in (23).
a. Dalam fungsionalisme / diakui/beberapa prinsip berikut: .... (SKF: 5)
In functionalism / are acknowledged / the following principles: ...
b. Dalam linguistik, / sering digunakan/istilah generatif. (SKF: 2)
In linguistics / is frequently used / the term 'generative'.

a. Dikisahkan// bahwa wanita pemarah ini mengupah seorang budak untuk membunuh Hamzah sebagai balas dendan atas kematian suaminya. (LP: 146) It was told // that the grumpy women once paid a slave to kill Hamzah to avenge the death of her husband.

b. Dapat dikatakan// bahwa Bu Mus sering kewalahan menghadapi Lintang \ terutama untuk pelajaran matematika, sehingga ia sering diminta membantu. (LP: 122)

It can be said // that $B u$ Mus was often so overwhelmed by Lintang, especially in maths, that he was often asked for help.

c. Dikemukakan// bahwa penyakit ini sering didapati di masyarakat sehingga kita perlu berupaya mengurangi penularan penyakit ini. (KO, 17/7/11)

It is mentioned // that the disease is so frequently found among the communities that we must strive to confine its spread.

The constructions in (22) begin with an adverb. The verb and verb phrase 'diakui' and 'sering digunakan' are placed before the subject. In (23), the verbs 'dikisahkan', 'dikatakan', and 'dikemukakan' are followed by a complex subject. In the samples, the complex subjects are clauses.

\subsection{Passive Verbs with Prefix 'ter-'}

Like the 'di-passive verb' construction, the P-S structure in passive constructions with 'ter-verbs' also have the same characteristics: (1) they begin with an adverb and (2) they have a complex subject or a combination between an adverb and complex subject.

a. Di papan tulis itu / terpampang / gambar matahari dengan garis-garis sinar berwarna putih. (LP: 18-19)

On the board / was displayed / the picture of the sun with its white rays.

b. Di balik kecantikannya / tersimpan / nyali yang kadang tak dipunyai pria. (KO, 29/11/12)

Behind her beauty / lies / the courage that some men do not have.

c. Kelihatannya memang enak, // dari bau bakarannya juga / tercium / aroma yang menggoda. (KO, 13/4/12)

It looks delicious, // from the grill // can be smelled / an appetizing aroma.

(25) a. Terbetik/kabar bahwa Intel sedang bersiap-siap merilis jajaran keluarga CPU 
dual-core untuk notebook tipis. (KO, 9/10/09)

Revealed has been / a rumor that Intel is preparing to release a series of dual-core CPU families for thin notebooks.

b. Dalam penelitian meta-analisis Hollman, / terbukti / bahwa mereka yang mengonsumsi teh tiga cangkir setiap hari memiliki pengurangan risiko terkena stroke hingga 20 persen. (KO, 10/12/12)

In Hollman's meta-analytical research, // it is proven / that those who consume three cups of tea every day will have their stroke risk reduced by 20 percent.

c. Pada penutup peti raja yang bengis itu / tertulis / "Barang siapa mengutak atik jasad Amir Timur akan dihancurkan musuh yang lebih beringas". (T, 12-18/9/11: 56)

On the lid of the cruel king's chest / was written / "Whoever tampers with Amir Timur"s body, will be crused by even fiercer enemies.

The constructions in (24) begin with an adverb. In the examples, the verbs 'terpampang', 'tersimpan', and 'tercium' are position before the subject. In (25), the verbs 'terbetik', 'terbukti', and 'tertulis' are followed by complex subjects, all of which are clauses.

\subsection{Passive Verbs with Circumfix 'ke-an'}

The P-S structure in passive constructions with passive verbs 'ke-verb-an' is shown in the following examples.
a. Di sana-sini / kedengaran / gerisik ranting patah. (LB: 55)
Everywhere / was heard/ the crackling sound of broken twigs.
b. Di sini / masihkelihatan / kekunoan kota-kota Prancis Selatan. (LB: 29)
Here / is still seen / the antiquity of South France cities.
c. Akhirnya, / Ketahuan Juga / Wujud Camry 2012 (KO, 11/8/11)
Finally / was revealed / Camry 2012's look.

The constructions in (26) begin with an adverb. In the examples, the passive verbs 'kedengaran', 'kelihatan', and 'ketahuan' are all placed before their subjects.

\section{Conclusion}

There are several types of constructions with P-S structure in Indonesian. Based on their communicative function, constructions with P-S structure can be found in (1) interrogative constructions, (2) imperative constructions, (3) exclamatory constructions, and (4) declarative constructions. Based on the category of word that functions as the predicate, declarative constructions are categorized into (1) declarative constructions with noun-phrase predicates, (2) declarative constructions with numeral-phrase predicates, (3) declarative constructions with adjective-phrase predicates, and (4) declarative constructions with verb-phrase predicates. Noun-phrase predicates are divided into (i) noun phrase + particle '-lah', (ii) nominal phrase whose subject is preceded by 'yang', (iii) noun phrase preceded/followed by an adverb, and (iv) the noun phrase 'tak seorang pun'. Verb-phrase predicates can be (i) stem verbs, (ii) verbs with prefix 'ber-', (iii) intransitive verb with prefix ' $m e N-$ ', and (iv) passive verbs. Stem verbs are categorized into (a) 'ada' verb and (b) other stem verbs. 
Passive verbs include (a) passive verbs without prefix, (b) passive verbs with prefix ' $d i-$ ', (c) passive verbs with prefix 'ter-', and (d) passive verbs with circumfix 'ke-an'.

This research is an initial stage to explore the diverse aspects related to the predicate-subject structure in Indonesian. Analysis is still elementary in nature, focusing on the categories that fill the position of predicates. Other aspects related to this problem, for example the syntactic behavior of each construction, the shift from subject-predicate to predicate-subject structure, semantic and pragmatic aspects of each construction have yet to be studied more deeply and more thoroughly.

\section{References}

Alwi, et al. (2003). Tata Bahasa Baku Bahasa Indonesia. Jakarta: Departemen Pendidikan dan Kebudayaan.

Chaer, Abdul. (2009). Sintaksis Bahasa Indonesia (Pendekatan Proses). Jakarta: Rineka Cipta.

Givon, T. (1984). Syntax A Functional-Typological Introduction. Amsterdam/Philadelphia:John Benjamins.

Kaswanti Purwo, Bambang. (1985). Inversion in Indonesian Narratives: Syntax and Discourse. For The Fourth Conference on Austronesian Languages, University of Michigan, Ann Arbor, August 1-3, 1985.

Kaswanti Purwo, Bambang. (1987). Subjek-Predikat dan Topik-Komen: Liku-likuPerkembangannya. $5^{\text {th }}$ Indonesian Linguistic Society Conference. Ujung Pandang, 22-27 July 1987.

Kaswanti Purwo, Bambang. (1989). Pola Urutan SV/VS dan Perubahan Struktur SintaktisBahasa Indonesia. In Atma nan Jaya, Majalah ilmiah Universitas KatolikIndonesia Atma Jaya, Juni 1989, Year 2, Number 2. Jakarta: Lembaga Penelitian AtmaJaya.

Kridalaksana, Harimurti. (1985). Tata Bahasa Deskriptif: Sintaksis. Jakarta: Pusat Pembinaan dan Pengembangan Bahasa.

Kridalaksana, Harimurti. (2002). Struktur, kategori, dan Fungsi dalam Teori Sintaksis. Jakarta: UniversitasKatolik Indonesia Atma Jaya.

Kridalaksana, Harimurti. (2007). Kelas Kata dalam Bahasa Indonesia. Jakarta: PT Gramedia Pustaka Utama.

Lapoliwa, Hans. (1990). Klausa Pemerlengkapan dalam Bahasa Indonesia. Yogyakarta: Kanisius.

Sudaryanto. (1992). Metode Lingustik. Yogyakarta: Fakultas Sastra dan Kebudayaan Universitas Gadjah Mada.

Sudaryanto. (1993). Metode dan Teknik Analisis Bahasa. Yogyakarta: Duta Wacana University Press. 
Sudaryanto. (1994). Predikat-Objek dalam Bahasa Indonesia: Keselarasan Pola Urutan. Jakarta: Djambatan.

Sugono, Dendy. (1995). Pelesapan Subjek dalam Bahasa Indonesia. Jakarta: Pusat Pembinaan dan Pengembangan Bahasa.

Tjung, Yassir. (2003). On Ada-Constructions in Indonesian. In Katharina Endriati Sukamto (Ed.), Cakrawala Baru. Jakarta: Yayasan Obor Indonesia.

Tuckyta Sari Sujatna, Eva. (2012). Applying Systemic Functional Linguistics to BahasaIndonesia Clauses. International Journl of Linguistic, 4(2). Macrothink Institute.

\section{Authors}

Wagiati (M.Hum.) is Lecturer at the Indonesian Departement, Faculty of Humanities in Padjadjaran University, Bandung, Indonesia.

Dadang Suganda (Prof. Dr.) is Professor at the Indonesian Departement, Faculty of Humanities in Padjadjaran University, Bandung, Indonesia.

Bambang Kaswanti Purwo (Prof. Dr.) is Professor at the English Departement, Faculty of Humanities in Atmadjaya University, Jakarta, Indonesia.

Wahya (Dr.) is Associate Professor at the Indonesian Departement, Faculty of Humanities in Padjadjaran University, Bandung, Indonesia. 